\title{
The first record of Orthostigma cratospilum (Thomson, 1895) (Hymenoptera: Braconidae, Alysiinae) in Poland, with a note on its host and a description of the female
}

\author{
Sergey A. BelokobylskiJ*, Piotr CeryngieR** and Ewa DurSKA* \\ *Museum and Institute of Zoology, Polish Academy of Sciences, Wilcza 64, 00-679 Warsaw, Poland; \\ e-mail:wcz@miiz.waw.pl; edurska@miiz.waw.pl \\ **Centre for Ecological Research, Polish Academy of Sciences, Dziekanów Leśny, 05-092 Lomianki, Poland; \\ e-mail: ceryngier@cbe.internet.dsl.pl
}

\begin{abstract}
The alysiine wasp, Orthostigma cratospilum, is reported for the first time from Poland (Dziekanów Leśny near Warsaw). It was found to parasitize the larvae of the phorid fly, Megaselia minor, which developed in dead pentatomid bugs, in the litter under pine trees. The hitherto unknown female of $O$. cratospilum is described.
\end{abstract}

Key words: Hymenoptera, Braconidae, Orthostigma, description of female, host, Diptera, Phoridae

\section{INTRODUCTION}

Genus Orthostigma Ratzenburg belongs to the Aspilota-group within the braconid subfamily Alysiinae. It can be easily distinguished from other Western Palaearctic genera of this group by the presence of coarse and curved submedian carina on the mandible and large, rounded third mandibular tooth. However, determination of most species of Orthostigma represents a serious problem because of their variation in the main diagnostic characters (Königsmann 1969).

$O$. cratospilum was described from the male and so far only males of this species have been known. In comparison with all other species of the genus Orthostigma, the males of $O$. cratospilum possess strongly enlarged pterostigma, whose maximum width is distinctly larger than the length of the first radial abscissa. However, the size and shape of pterostigma is in Orthostigma a character showing clear sexual dimorphism and thus it could not be useful in seeking out $O$. cratospilum females.

Members of the subfamily Alysiinae are known as endoparasitoids of the larvae of Diptera. In the Aspilota-group, the main hosts are larvae of the scuttle flies (Phoridae) (Shenefelt 1974, Achterberg 1988). Records of Agromyzidae, Drosophilidae and Sepsidae as hosts of Aspilotagroup are probably erroneous as resulting from mass rearings (Achterberg 1988).

Herein we report for the first time the occurrence of $O$. cratospilum in Poland, provide information on its newly recorded host species and describe the hitherto unknown $O$. cratospilum female.

\section{MATERIAL AND METHODS}

During two late autumn-winter seasons, 2000/2001 and 2001/2002 various dead insects were collected from the litter under Scots pines (Pinus sylvestris L.) growing at the edge of a forest clearing in Dziekanów Leśny near Warsaw (central Poland) to check their infestation by entomopathogenic Hyphomycetes (Fungi Imperfecti). The collected insect corpses were placed in humid chambers (Petri dishes with moist filter paper) at $25^{\circ} \mathrm{C}$ to stimulate growth and 
sporulation of the fungi on infected specimens. From some cadavers of large bugs of the family Pentatomidae dipteran larvae (several larvae per a bug) emerged and pupariated. They gave rise to either adult phorid flies subsequently identified as Megaselia minor (Zetterstedt) or their parasitoids, the alysiine wasps.

\section{RESULTS}

Because the parasitic wasps in our material were reared from one host species obtained in one locality and habitat, we can assume that the specimens of both sexes belong to the same species. The males, after comparison with the lectotype of $O$. cratospilum (male, "Möl", "cratospila m", "Lectotype O. cratospila, Königsmann", "§゙", "Orthostigma cratospila Тн."; Lund University, Sweden), appeared to be males of this species and, hence, female specimens could be attributed to the hitherto unknown $O$. cratospilum females.

Examination of male and female specimens of $O$. cratospilum revealed sexual differences in the size (mostly width) of pterostigma and in the length of the second radiomedial cell. In males, this cell is long and narrow (3.5-4.1 times as long as wide) while in females it is shorter (about 3.0 times as long as wide).

The first description of the female of $O$. cratospilum is presented below. The terminology for wing venation follows that of Belokobylskij \& Tobias (1998).

\section{Orthostigma cratospilum (Thomson, 1895)}

\section{(Figs 1-13)}

Alysia (Orthostigma) cratospila: Thomson 1895: 2300.

Orthostigma cratospilum: Königsmann 1969: 9, Fischer 1971: 101, Shenefelt 1974: 997; Achterberg \& Ortega 1982 (1983): 124, Tobias 1986: 117, Fischer 1995: 682, Belokobylskij 1998: 210.

Material. All specimens examined were obtained from Megaselia minor developing inside the cadavers of Pentatomidae (Heteroptera). Two females originated from one Palomena sp. cadaver collected on 4 December 2000 (emergence: January 2001); 2 males and 1 female originated from the cadaver of Pentatoma rufipes (L.) collected on 22 November 2001 [emergence: 7-9 December 2001 (male), 10-16 December 2001 (female), 1-2 January 2002 (male)].

Description. Female (the first record). Body length 2.1-2.5 mm; fore wing length 2.1-2.4 mm. Head width 1.6-1.8 times its median length, 1.4-1.5 times its maximum length, 1.4-1.5 times width of mesoscutum. Head just behind eyes convex, then roundly narrowed (dorsal view). Width of head at the level of temple equal to or slightly larger than its width at the level of eyes. Transverse diameter of eye 1.2-1.4 times length of temple. Ocelli in almost equilateral triangle. POL 1.0-1.2 times Od, 0.35-0.45 times OOL. Maximum diameter of eye 1.2 times its minimum diameter. Face width 1.2-1.3 times its median height (with antennal tubercles), 1.1-1.2 times maximum diameter of eye. Width of clypeus 2.2-2.5 times its median height, 0.8-0.9 times width of face. Tentorial pits medium size, situated in lower part of face. Mandible short and wide, its median length almost equal to maximum width. Upper tooth small, but distinct and pointed apically, directed slightly upwards, significantly shorter than median tooth. Median tooth rather wide, pointed, longer than the other ones. Lower tooth very wide, regularly rounded.

Antennae almost filiform but somewhat thickened medially, with no deep constrictions in base of segments, 21-22-segmented, as long as body. Scapus 1.4-1.6 times as long as its maximum width, 0.7-0.8 times as long as first flagellar segment. First flagellar segment 3.03.5 times as long as its apical width, 1.1-1.2 times as long as second segment, second segment 2.3-2.6 times as long as its width and submedian segments 1.8-2.1 times as long as wide. Penultimate segment 1.8-2.2 times as long as wide, 0.5-0.6 times as long as first flagellar segment, 0.8-0.9 times as long as apical segment; the latter rounded apically. 

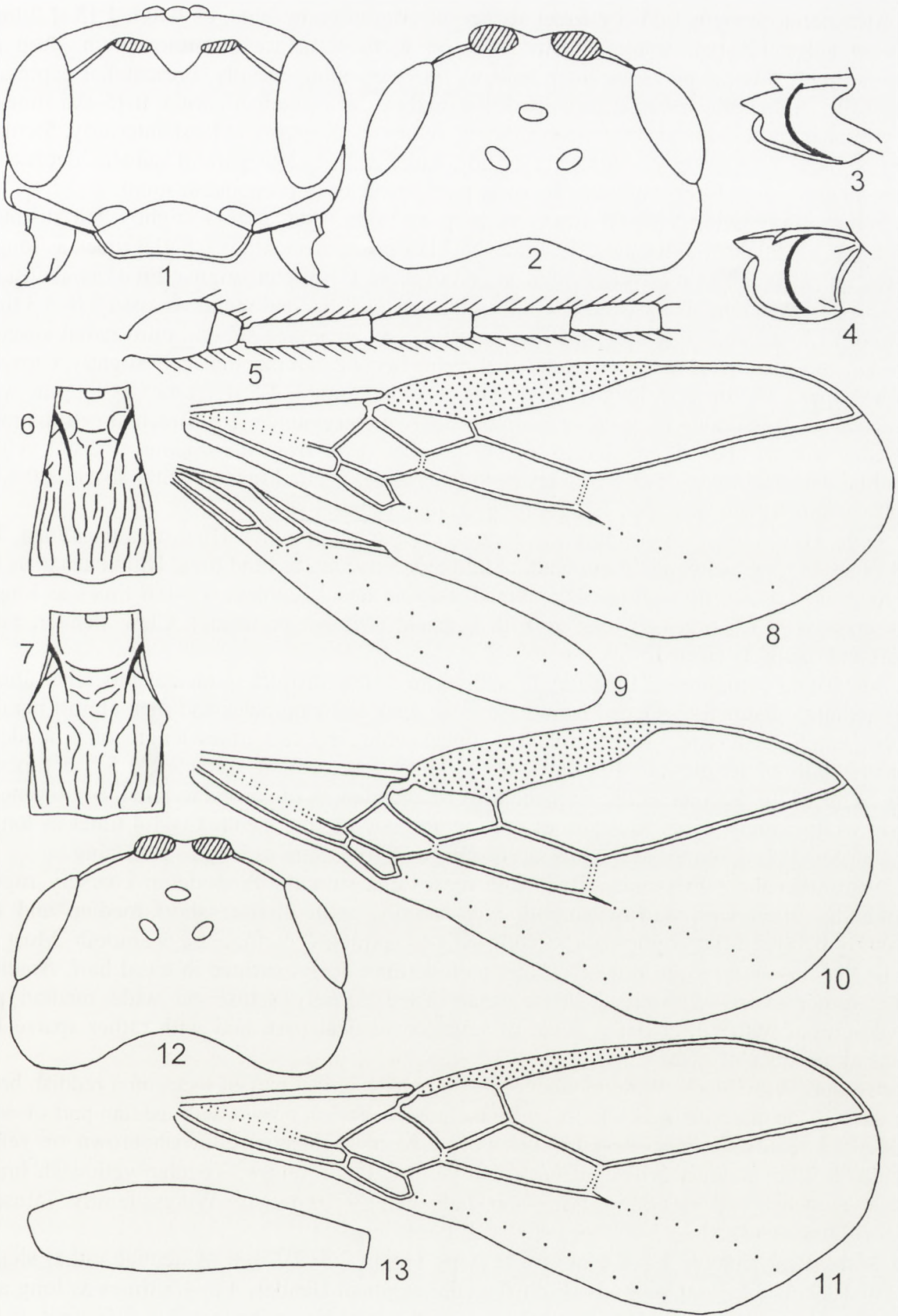

Figs 1-13. Orthostigma cratospilum (THOMSON) (1-10, 13 - male; 11, 12 - female; 1-4, 6, 8, 9, 13 - lectotype; 5, 7, 10-12 - specimens from Poland). 1 - head, front view; 2, 12 - head, dorsal view; 3,4 - mandible ( 3 - view on upper tooth; 4 - view on lower tooth); $5-6$ basal segments of antenna; 6, 7 - first metasomal tergite; 8, 10,11 - fore wing; 9 - hind wing; 13 - hind femur. 
Mesosoma. Length 1.25-1.3 times its height. Mesoscutum wide, its width 1.15-1.2 times median length. Notauli short, situated only on vertical surface of mesoscutum, deep and crenulate. Mesoscutal pit rather long, narrow, finely crenulate usually. Prescutellar depression deep, almost smooth or sometimes sparsely rugulose, with median carina, $0.45-0.5$ times as long as scutellum. Subalar depression shallow, rather wide, rugose at least anteriorly. Sternauli long, oblique, distinctly crenulate, anteriorly fused with below part of subalar depression. Mesopleural suture finely crenulate in lower half. Spiracles of propodeum small.

Wings. Fore wing 2.3-2.6 times as long as wide. Pterostigma slightly but distinctly widened, not thickened. Radial cell somewhat shortened; metacarpus $0.8-0.9$ times as long as pterostigma. Radial vein arising from near end of basal 1/3 of pterostigma. First radial abscissa 1.3-1.4 times as long as maximum width of pterostigma. Second radial abscissa 3.0-3.3 times as long as first radial abscissa, 0.35-0.4 times as long as almost straight third radial abscissa, 1.6-1.7 times as long as first radiomedial vein. Second radiomedial cell slightly narrowed toward apex, 3.0 times as long as wide. Discoidal cell small, 1.5-1.7 times as long as wide. Distance from nervulus to basal vein almost equal to nervulus length. Brachial cell distinctly widened toward apex. Parallel vein arising just before or from the middle of distal vein of brachial cell. Hind wing 5.0-5.3 times as long as wide. Second mediocubital abscissa 0.4-0.5 times as long as first abscissa, 1.3-1.4 times as long as basal vein.

Legs. Hind femur 3.5-4.0 times as long as its maximum width. Hind tibia thickened, 7.0 8.0 times as long as its maximum width. Hind tarsus as long as hind tibia. Hind basitarsus half as long as second-fifth segments combined. Second tarsal segment 0.5-0.6 times as long as basitarsus, 1.4-1.6 times as long as fifth segment (without pretarsus). Claw slender, rather short and regularly curved.

Metasoma compressed. First tergite with more or less distinct spiracular tubercles situated submedially, distinctly widened from base to its apex or to spiracles and then almost parallelsided; length of tergite 1.4-1.6 times its apical width, 1.1-1.3 times length of propodeum; apical width of tergite 1.1-1.3 times its width at the level of spiracles, 1.5-1.6 times its minimum width. Second suture very shallow. Median length of second tergite $0.8-1.0$ times its basal width, almost equal to length of third tergite. Ovipositor sheath 1.0-1.4 times as long as first tergite, 0.4-0.6 times as long as mesosoma, 0.15-0.2 times as long as fore wing.

Sculpture and pubescence. Head and mesosoma smooth. Propodeum coarsely rugosereticulate, often with narrow smooth area basally, with distinct short median and then strongly divergent lateroposteriorly (following to spiracles) carinae. Legs smooth. Most part of first metasomal tergite rugose-striate, with distinct dorsal carinae in basal half. Antennae with rather short, semi-erect, dense setae. Face densely setose on wide median part. Mesoscutum with rather dense setae on anterior vertical part, and with rather sparse long setae along trace of notauli.

Colour. Body black. Wide median part and narrow apical part of metasoma reddish brown on dorsal side or sometimes almost entire metasoma reddish brown with median part of dorsal side light reddish brown. Antenna black, two basal segments yellowish brown or yellow. Mandible light reddish brown or brownish yellow. Palpi yellow. Tegulae yellowish brown. Legs brownish yellow, hind tibia and tarsi faintly infuscate. Wings faintly infuscate. Pterostigma brown.

Male. Body length 2.1-2.5 mm; fore wing length 2.3-2.7 mm. Antennae rather slender, about 1.2 times as long as body. First flagellar segment slender, 4.0-4.3 times as long as its apical width; second segment 3.3-3.5 times and submedian segments 2.3-2.5 times as long as wide. Mesoscutal pit almost smooth. Pterostigma strongly widened, distinctly sclerotized. First radial abscissa $0.4-0.5$ times as long as maximum width of pterostigma. Second radial abscissa 4.0-5.0 times as long as first radial abscissa, 0.35-0.4 times as long as third radial 
abscissa, 1.6-2.0 times as long as first radiomedial vein. Second radiomedial cell 3.5-4.0 times as long as wide. Hind femur 3.3-3.7 times as long as its maximum width. Otherwise similar to female.

\section{DISCUSSION}

The majority of the species of the genus Orthostigma were described from specimens of one sex and in many cases [e.g. O. lucidum Königsmann, O. longicubitale Königsmann, $O$. sibiricum (Telenga), O. breviradiale Königsmann] specimens of the other sex have still not been recognized (Fischer 1995). Species of Orthostigma often show considerable sexual dimorphism, which implies that (1) discovery of other sex by studying collection material only is rather problematic and (2) it is possible that males and females of one species could be described as separate species.

To discover for a certainty the unknown sex of a given Orthostigma species, it is necessary to perform some experimental work or to obtain in the field a highly consistent material comprising wasps of both sexes. It seems that our wasps, as being reared from one host species collected in one locality and one habitat, fulfil the latter condition.

It is likely that the female of $O$. cratospilum has already been described under another specific name. $O$. cratospilum females in our material are similar to the lectotype (female) of O. sibiricum (Telenga) (female, brown ring, "Sibir', Kuznetzkiy okr[ug], Kemerovo, 14/VI.[19]27, A. Karpov", "Aspilota sibirica sp. n., N. Telenga det.", "Orthostigma sibiricum q (Tel.), det. Fischer, Lectotype von Aspilota sibirica Tel.", "Lectotypus"; Zoological Institute, St. Petersburg, Russia). Both possess oblique lateral furrow between antennal socket and the margin of eye. Although $O$. cratospilum differs from $O$. sibiricum in having longer radial cell of fore wing and distinctly postfurcal position of nervulus, it is quite possible that these differences are within-species variation only.

Host records of $O$. cratospilum so far reported include a drosophilid Parascaptomyza pallida (Zetterstedt) and a sepsid Themira annulipes (Meigen) (Shenefelt 1974). These records, however, are most probably erroneous as being a result of mass rearing. Our finding of $M$. minor as a host of $O$. cratospilum confirms a principal role of phorids as hosts of alysiines belonging to the Aspilota-group.

\section{ACKNOWLEDGEMENTS}

We wish to express our sincere thanks to Dr. R. Danielsson (Lund, Sweden) for enabling us to study the type of Thomson species.

\section{REFERENCES}

ACHTERBERG C. VAN 1988. The genera of the Aspilota-group and some descriptions of fungicolous Alysiini from the Netherlands (Hymenoptera: Braconidae: Alysiinae). Zool. Verhand. 247: 3-88.

AChterberg C. VAN \& ORTEGa G. (1982) 1983. A new species of Orthostigma Ratzeburg from Tenerife (Insecta: Hymenoptera: Braconidae). Vieraea 12: 121-127.

BelOKOB YLSKIJ S.A. 1998. Subfam. Alysiinae. Tribe Alysiini. In: Lehr P.A. (ed.). Opredelitel' nasekomykh Dal'nego Vostoka Rossii [Keys to the Insects of the Russian Far East]. Vladivostok: Dal'nauka. 4 (3): 163-298. (In Russian).

BElokobylskiJ S.A. \& Tobias V.I. 1998. Fam. Braconidae. Introduction. In: Lehr P.A. (ed.), Opredelitel' nasekomykh Dal'nego Vostoka Rossii [Keys to the Insects of the Russian Far East]. Vladivostok: Dal'nauka. 4 (3): 8-26. (In Russian).

FISCHER M. 1971. Untersuchungen über die europäischen Alysiini mit besonderer Berücksichtigung der Fauna Niederösterreichs (Hymenoptera, Braconidae). Polskie Pismo Entomol. 41: 19-160.

FISCHER M. 1995. Über die altweltlichen Orthostigma-Arten und Ergänzungen zur Aspilota-Gattungsgruppe (Hymenoptera, Braconidae, Alysiinae). Linzer biol. Beitr. 27: 669-752.

KÖnIGSMANn E. 1969. Beitrag zur Revision der Gattung Orthostigma. Deutsche entomol. Zeitschr. N.F. 16 (1/3): 1-53. 
Shenefelt R.D. 1974. Hymenopterorum Catalogus. Pars 11. Braconidae 7. Alysiinae. s'-Gravenhage: Dr. W. JunK, pp. $937-1113$.

TOBIAS V.I. 1986. Subfam. Alysiinae. In Medvedev G.S. (Ed.). A key to the insects of the European part of the USSR. Hymenoptera. 3(5): 100-231.

Thomson C.G. 1895. LII. Bidrag till braconidernas kännedom. Opuscula entomologica. 20: 2141-2339.

\section{STRESZCZENIE}

[Pierwsze stwierdzenie Orthostigma cratospilum (Thomson, 1895) (Hymenoptera: Braconidae, Alysiinae) w Polsce wraz z danymi dotyczącymi gatunku żywicielskiego i opisem samicy]

Praca zawiera pierwsze doniesienie o występowaniu w Polsce pasożytniczej błonkówki Orthostigma cratospilum (Thomson). Zamieszczony został również pierwszy opis samicy parazytoida oraz dane dotyczące jego żywiciela - muchówki Megaselia minor (Zetterstedt). Rozwój larwalny $M$. minor przebiegał wewnątrz martwych pluskwiaków z rodziny Pentatomidae, znalezionych w ściółce pod sosnami w Dziekanowie Leśnym k/Warszawy. $O$. cratospilum okazał się parazytoidem larw M. minor. 